\title{
A conceptual and empirical study on the development of the Islamic donation-based crowdfunding platform model for micro small and medium-sized enterprises (MSMEs) in times of Covid-19 pandemic in Indonesia
}

\author{
Sulaeman* \\ Faculty of Economics and Business, Airlangga University, Surabaya, Indonesia \\ *Corresponding author: sulaeman-2019@feb.unair.ac.id
}

\begin{abstract}
Purpose: This study aims to present and to test practically the concept of the Islamic donation-based crowdfunding platform model for providing the financing program of MSMEs in times of COVID-19 pandemic in Indonesia.
\end{abstract}

Methodology: This study uses a conceptual and empirical approach. The primary data is collected through the online survey questionnaires and then the data are descriptively analyzed.

Findings: This research finds that the concept of the Islamic donation-based crowdfunding platform model is expected to solve the existing problems due to the adverse impact of the Covid-19 pandemic on MSMEs in Indonesia. Also, the platform model will open the opportunity for more optimum and impactful utilization of Islamic charity donation funds from zakat, cash waqf, sadaqah, and the like. Besides, an empirical study finds the majority of respondents accepted the concept of the Islamic donation-based crowdfunding platform model. The platform model has the potential to optimize financing programs for MSMEs in times of the Covid -19 pandemic situation.

Practical implications: The present study also has implications for government, zakat institution, waqf institution, and policymakers to realize the concept of the Islamic donation-based crowdfunding platform model into the real world.

Originality: The study will contribute to the existing literature especially on the Islamic donation-based crowdfunding platform model as an alternative strategy to minimize the negative impact of the Covid-19 pandemic on MSMEs in Indonesia.

Keywords: Islamic charity donation, Islamic Donation-based crowdfunding, financing program, MSMEs, Covid -19 pandemic, Indonesia.

Cite this article:

Sulaeman. (2020). A conceptual and empirical study on the development of the Islamic donation-based crowdfunding platform model for micro small and mediumsized enterprises (MSMEs) in times of Covid-19 pandemic in Indonesia. Asian Journal of Islamic Management, 2(2), 107-122. https://doi.org/10.1108/AJIM.vol2.iss2.art4
Article History

Received, 02 September 2020

Revised 1, 23 October 2020

Revised 2, 12 November 2020 Accepted, 20 November 2020

\section{Introduction}

Nowadays, the problematic phenomena of Corona Virus Disease 2019 (Covid -19 - the current term of the virus) have been becoming a disease issue worldwide (Chamani et al., 2020). The Covid -19 is not only a medical problem which is a global pandemic but also becomes economic problems for many countries in the world. Based on the data from London Business School (2020), there are 
several sectors affected by the Covid -19 pandemic i.e. the tourism and hospitality sectors, airline, oil and gas, automotive, customer product, and electronics, and semi-conductors (Ascarya, 2020). Furthermore, in Indonesia, the Covid -19 pandemic had a huge impact on economic conditions. Sri Mulyani Indrawati, as Minister of finance Indonesia, stated that the current crisis caused by the Covid -19 pandemic was far more complex instead of the 1997-1998 and 2008-2009 crises (Victoria, 2020). In line with that, the Covid -19 pandemic had a significant impact on decreasing the welfare of society, for instance, rising the amount of unemployment and poverty.

According to experts' predictions, MSMEs which depend on daily liquidity will suffer the greatest impact from the Covid -19 that can cause bankruptcy. However, MSMEs are the dominant sector in Indonesia's economic structure. In line with the data from the Ministry of Cooperatives and Small and Medium-sized Enterprises (Kementerian Koperasi dan Usaha Kecil Menengah, 2018), the number of MSMEs is approximately 64 million which absorbs more than 113 million workers or $93.88 \%$ of the total workforce. The total contribution of MSMEs to Indonesia's 2018 GDP is approximately $57 \%$, or IDR $8,457.3$ trillion when Indonesia's economic growth is $5.20 \%$ and decreases to become IDR 6,830 trillion when Indonesia's economic growth is $4.20 \%$ during the Covid -19 pandemic based on the projection of Puskas Baznas (2020). Thus, this phenomenon has been taken into account. Not only government institutions but also all parties in Indonesia should overcome this matter togetherly.

Many scholars, practitioners, academicians, and society have been discussing through webinar (an online discussion forum) for seeking solutions in along times of Covid -19 outbreaks. According to Mukhlisin et al. (2020), one of the effective solutions is optimized of the potential of Islamic financial technology (Islamic FinTech) in which is an emerging element that has enormous spread in Indonesia, especially for providing a financial solution (Riza \& Hafizi, 2020). The development of an Islamic crowdfunding model based on the website platform was deemed as a pivotal step for MSMEs in Indonesia. The concept of Islamic crowdfunding can be a solution to any problems in MSMEs. If the lack of funding, Islamic crowdfunding will be providing funding, apart from banking (Marzban et al., 2014).

On the other hand, Indonesia as the biggest Muslim population, Islamic charity funds such as from zakat, waqf, sadaqah, and the like, are the potential funding for overcoming problematic issues that are being faced by ummah nowadays. As an example, the prospective accumulation of zakat, waqf, and other charities is highly immense (Indrawan \& Herman, 2017). In Indonesia itself, the total of all zakat potential is approximate IDR 217 trillion from various sources. This number is equal to 3.4\% of Indonesia's 2010 GDP (Firdaus et al., 2012). Meanwhile, there is another potential resource which is cash donation in the form of waqf. This cash waqf donation is popular among Muslim society recently (Indrawan \& Herman, 2017). According to Iwan Agustiawan Fuad, as a commissioner of the Indonesian Waqf Board (Badan Wakaf Indonesia), states that the total potential for cash waqf in Indonesia had reached IDR 77 trillion, nonetheless, at the end 2018, the collection of cash waqf was only 225 billion rupiahs from IDR 77 trillion (Sitanggang, 2019).

Therefore, based on the above explanation, this paper aims to explore the potential of Islamic charity donation funds from zakat, cash waqf, and other charities and the concept of the Islamic crowdfunding as an intermediary between Muslim donors and MSMEs. Following that, the paper proposes a conceptual of the Islamic donation-based crowdfunding platform model as a mode of financing services for supporting MSMEs in times of Covid-19 pandemic situation in Indonesia. Besides, the online survey was conducted to test practically the concept of the platform model from the perspective of the donors who are represented by respondents who can access financial technology especially know and ever participate in the type of donation-based crowdfunding such as kitabisa.com, ayopeduli.id, or other like. More importantly, based on the best of the author's knowledge, the study will help the government and policymakers to minimize the adverse impact of the Covid-19 pandemic on MSMEs in Indonesia and this study also will contribute to the existing literature on Islamic FinTech especially the Islamic donation-based crowdfunding platform model. 


\section{Literature Review}

\section{Charity Donation in Islam}

The charity donation in Islam can take several forms: Firstly, zakat, it means "purity" and "cleanness." The payment of zakat purifies and cleans the wealth and the heart of the person who pays qakat (muzakki). It cleans the dirt of wealth as well as the heart of the qakat payer. By removing the stringiness, zakat purifies the heart of the zakat payer and prepares him to sacrifice for the cause of Allah (Samad \& Glenn, 2010). The other meaning of zakat is fertility or growth. The payment of zakat is designed to enable the poor to grow in wealth and spirit. The establishment of zakat payment has several objectives, namely: to eradicate poverty and maintain socioeconomic justice; safeguard wealth from the jealousy of the others, the poor in particular; purify one's wealth and remove one's stringiness, and remain thankful to Allah for His bounty to him (Samad \& Glenn, 2010). Moreover, Zakat is taken from specific sources of wealth and given to specific categories of recipients (mustabik). The specific sources of wealth include livestock, savings, trade goods, crops, and minerals (Indrawan \& Herman, 2017). The categories of eligible recipients for zakat are mentioned in the Quran chapter 9 verse 60 states: 'Alms are only for the poor and the needy, and those who collect them [rakat], those whose hearts are to be reconciled, captives, debtors, in the cause of Allah, and wayfarers...'.

Secondly, waqf, or Islamic endowment fund. where waqf is a continuous charity that confers continuing rewards upon the donor and lasting benefits to the public (Mauluddin \& Rahman, 2018). From an economic aspect, waqf connotes the transfer of wealth from being exhausted to being profitable, with social equity turning it into a productive asset fruitful for the future of the individual and society (Mauluddin \& Rahman, 2018). The form of waqf assets is not limited to permanent property but can also be transferable, such as cash waqf (Mauluddin \& Rahman, 2018). Which cash waqf was established by using money to provide services to people in the name of Allah. The popularity of cash waqf has recently increased rapidly in Muslim societies (Cizakca, 1995). Where it is proven by many wealthy Muslims have been giving cash in the form of waqf to specific institutions; the funds are used for providing social services to the vulnerable groups of society (Cizakca, 1995). Currently, there are several models of cash waqf which have been developed for socio-economic development (Che et al., 2018; Kachkar, 2017; Sulistiyo, 2020); for poverty alleviation (Kachkar, 2017; Mohammad, 2015; Raimi et al., 2014); for micro-enterprises (Thaker et al., 2016; Tohirin, 2010); for waqf institutions (Thaker, 2018); for education (Aziz et al., 2013); for microfinance (Abdullah \& Ismail, 2017; Haneef et al., 2013); for use by financial institutions (Mohammad, 2011); for entrepreneurship (Iman \& Mohammad, 2017); for Muslim refugees (Kachkar, 2017).

Finally, another form of charity donation in Islam is sadaqah, infaq, and kafarah. The sadaqah is another form of charity donation that is performed in various ways such as donation of used clothes, helping with money or providing food to the needy people. The core aim behind the act of sadaqab is to save oneself from evil spirits. Kafarah is another form of charity donation among Muslims which is performed where an oath has been broken down and can take the form of helping others with money or otherwise (Kashif et al., 2018).

\section{The Concept of Islamic Crowdfunding}

Crowdfunding is part of financial technology (fintech) segments that provide financing for individuals and businesses (Harahap et al., 2017). Fintech has become a trend in Indonesia, including crowdfunding (Aulia et al., 2020). Many researchers have defined and conceptualized the concept of crowdfunding in a variety of ways. But in the majority of the definitions, crowdfunding is known as a process of collection of funds (in a small amount) by entrepreneurial individuals and groups from a relatively large number of donors or investors by using the website platform/internet to fund a specified project, business venture or for the social project (Belleflamme, et al., 2014; Dresner, 2014; Mollick, 2014; Suhaili \& Palil, 2016; Thaker, 2018). 
In Islamic perspectives, Achsien and Purnamasari (2016) described that the crowdfunding model in Islam is like the use of small amounts of money obtained from a large number of individuals or organizations, to fund a project, a business or personal loan, and other needs through an online web-based platform based on with shariah principles. Some basic features are distinguishing Islamic crowdfunding from conventional one, as follows: (1) intentions and halal projects, (2) the free usury (riba), gambling (maysir), speculation (gharar), and (3) the existence of Shariah supervisory board (Achsien \& Purnamasari, 2016). Additionally, the requirements of the Islamic crowdfunding involve project initiators (e.g. individuals, organizations, and businesses); potential funders (PF); crowdfunding operators (CFO); the board of Sharia (Marzban et al., 2014).

The Islamic crowdfunding can be divided into four types, namely: (1) Donation-based crowdfunding: This type is made for the purpose such as social project or purely philanthropic perspective which is usually managed by NGO's. Contributors do not receive tangible benefits in exchange for their donations; (2) Reward-based crowdfunding: This type is the collection of funds, where contributors receive some tangible reward, such as a membership rewards scheme, as a token of appreciation for their contribution. They back these projects for social motivations; (3) Debtbased crowdfunding or lending-based crowdfunding: This type is investors who provide loans to startups or small enterprises to support their ventures; (4) Equity-based crowdfunding: This type is when investors offer equity funds in the business venture for supporting startups or small enterprises. The main motivation of investors is to get a return in the form of profit-sharing on their investment (Harahap et al., 2017; Hidajat, 2019; Marzban et al., 2014; Ramos, 2015; Sangwan et al., 2019; Thaker, 2018).

The advantage of the concept of Islamic crowdfunding is opened up a new source of funding for entities/community/groups, the ability to attract the emotional interest of donors to contribute and donate irrespective of geography, and a low-cost way of accessing funding (Suhaili \& Palil, 2016). Islamic crowdfunding also provides an opportunity for investors, donors, and entrepreneurs for the socio-economic development of the micro small and medium-sized enterprises (MSMEs) sectors in Islamic countries (Marzban et al., 2014).

\section{Legal Aspects of Islamic Crowdfunding in Indonesia}

There are three legal aspects of Islamic crowdfunding in Indonesia issued by government authorities, namely:

(1) The regulations of the National Shariah Council of the Indonesian Ulema Council (Dewan Syariah Nasional Majelis Ulama Indonesia (DSN-MUI)) Fatwa Number 117/DSN-MUI/II/2018 on the compliance of the information technology-based financing services with the Shariah principles.

(2) The regulation of the Indonesian Financial Services Authority or Peraturan Otoritas Jasa Kenangan (POJK) Number 77/POJK.01/2016 on the information technology-based lending and borrowing services.

(3) Bank Indonesia Regulation (Peraturan Bank Indonesia, PBI) Number 19/12/PBI/2017 on the Implementation of Financial Technology (Bank Indonesia, 2017).

\section{A Conceptual of Islamic Donation-Based Crowdfunding Platform Model}

In this section, the author proposes a concept of an Islamic donation-based crowdfunding platform model that can be the potential for supporting financing program MSMEs in Indonesia, especially in times of COVID-19 pandemic situation. Parties involved in this type of Islamic crowdfunding arrangement include:

(1) Micro small and medium-sized enterprises (MSMEs)/Entrepreneurs;

(2) Fund providers, including individual and institutional donors;

(3) A crowdfunding operator (CFO); and

(4) Shariah supervisory board. 


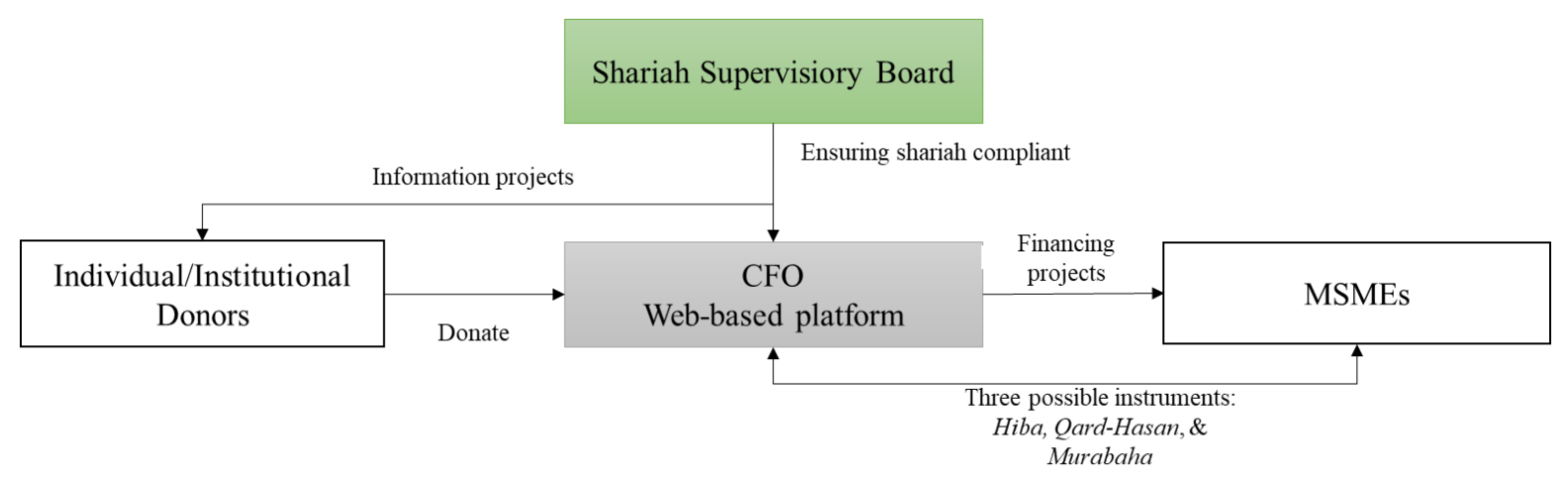

Source: Authors' Illustration

Figure 1. Illustration Scheme of Islamic Donation-Based Crowdfunding Platform Model model is:

As illustrated in Figure 1, the scheme of the Islamic donation-based crowdfunding platform

- CFO plans various financing services/programs such as to finance entrepreneurship training, to provide basic capital, to develop digital applications, to provide the procurement of raw materials or equipment production, and other projects for supporting MSMEs.

- Next, CFO will be offered in the form of a written prospectus, video presentation, infographic, and other forms of publication to the system which is known as a web-based platform and social networks.

- Or MSMEs/Muslim entrepreneurs also can propose the necessity project that will be funded by donors using the platform.

- Donors browse the Web and finally choose the projects that they are willing to support. If the donors select the zakat as the type of support then the list will contain the information for the zakat project or if the donors select the waqf support then the list will contain the information for the waqf project, and similarly if the donors select the sadaqab/other donation charities.

- Donors transfer/send funds through payment channels such as LinkAja Syariah, PayTren, Mobile banking, and another channel. CFO can have its payment channels through collaboration with existing financial institutions (Islamic banks).

- After the target amount of funds from donors is reached, the received funds are ready to be distributed to the proposed projects earlier for support MSMEs.

- MSMEs/Muslim entrepreneurs must register and must provide the need document on the platform to support the verification of the needs and classify them into valid or invalid categories project.

- To ensure transparency, CFO must up to date the progress regularly and updates the progress into the system until the particular projects are completed.

- A Shariah supervisory board needs to be established to ensure that the entire crowdfunding process complies with shariah principles.

\section{The Potential of Utilizing of Islamic Charity Donation Funds for MSMEs in the Current of COVID-19 Situation}

In this section, the author discusses the potential of utilizing Islamic charity donation funds in the Islamic donation-based crowdfunding platform model for MSMEs in times of Covid-19 pandemic. Three possible instruments i.e. Hibah (grant), Qard-Hasan (benevolent loan), and Murabahah (deferred payment sale) can be applied to the platform model such as suggested by Marzban et al., (2014). Furthermore, the platform model is divided into two components, which are: (1) the rakat and other charities fund like sadaqah or infaq, and (2) cash waqf fund. Where Zakat and other charities fund will be utilized for several purposes: 
- To finance entrepreneurship training for MSMEs to enhance their capability (e.g. digital marketing skill).

- To provide basic capital for MSMEs after entrepreneurship training. The basic capital can be provided based on bibah or qard al-hasan. Where the scheme of qard al-basan is specifically for MSMEs that can still be affected but still carry out production, it is just constrained by the difficulty of access to capital. Meanwhile, the scheme of hibah, this scheme is especially for micro-entrepreneurs that are difficult for the needs of daily life.

- To provide and to fulfill basic need "sembako" for the MSMEs to maintain their life, especially for micro-enterprises due to directly impacted Covid-19.

- To stimulate for debt repayment for MSMEs particularly micro-enterprises who are still in debt to Islamic microfinance institutions (Baitul Maal wat Tamwil (BMT), cooperatives (Koperasi Jasa Keuangan Syariah (KJKS)) or Islamic financial institutions (e.g. rural banks, commercial banks).

- Other charities fund (i.e. shadaqah, infaq, or the like in small amounts) can be accepted from donors. Then, the funds will be channeled to reserve funds and reserve risk funds. Hence, the main objective of reserve funds will be covered the operational expenses such expenses may include staff salaries, utility bills, office rents, and others. While, the function of risk reserve funds is as back up funds in case of any losses from mudharabah or murabahah scheme.

Meanwhile, the cash waqf fund by a manager will be channeled to investment, either real investment or low-risk shariah-compliant financial instruments, to generate returns. Thus, the returns of cash waqf fund will be utilized for several purposes:

- To expand the business of MSMEs. The possible instruments to use would be to use the mudharabah scheme. Where this scheme is for MSMEs affected but still able to survive and able to adapt during the Covid-19. pandemic but require additional capital. In this mudharabah scheme, MSMEs (as mudharib) will be guaranteed with reserve risk funds from other charities fund channeled in the form of debt which means will be used to cover losses.

- To provide the procurement of raw materials or equipment production for MSMEs sustainable, the possible instruments to use would be murabahah.

- To subsidize profit-margin for MSMEs on Islamic microfinance institutions (Baitul Maal wat Tamwil (BMT), cooperatives (Koperasi Jasa Keuangan Syariab (KJKS)) or Islamic financial institutions (e.g. rural banks, commercial banks). The cash waqf returns will subsidize the profitmargin, while the MSMEs will pay only the principal, like in qard al- hasan. However, the subsidy from cash waqf returns only applicable for MSMEs due to directly impacted Covid-19..

- To provide online commerce, the return of cash waqf could be used in the development of online commerce for MSMEs while maintaining physical distancing and a new normal era.

\section{An Empirical Study}

In this section, the author discusses the results of the online survey about acceptance of the concept of the Islamic donation-based crowdfunding model from the perspective of the donors who represented by respondents ever participate in the type of donation-based crowdfunding such as kitabisa.com, ayopeduli.id, or other like. The discussion is divided into two main subsections: Research methods and results and discussion.

\section{Research Methods}

This study used an online survey questionnaire to test the acceptance practicality of the idea about the concept of the Islamic donation-based crowdfunding platform model. The questionnaire contains five constructs variables: Perceived usefulness (6 question statements), perceived usefulness of model (6 question statements), use of social media (4 question statements), Islamic crowdfunding information ( 3 question statements), and donors' intention to use ( 2 question 
statements). In total, 21 question statements were distributed in May 2020 which were in Bahasa Indonesia. And the question statements are measured by a five-point Likert scale, where $1=$ strongly agree, $2=$ agree, $3=$ neutral, $4=$ disagree, and $5=$ strongly disagree.

The respondents were selected 193 donors/fund providers using the purposive sampling with boundaries according to the respondents' characteristics (see Appendix I the distribution of respondents); The sampling criterion in this study was people who can access FinTech services, especially crowdfunding like KitaBisa.com as donation-based crowdfunding in Indonesia, with a smartphone in the various demographics, geographic areas in Indonesia. Furthermore, this study used both secondary data and primary data. Where Secondary data are obtained from various existing sources such as books, reports, journals, and other publications. Meanwhile, the primary data are obtained directly from the sources through the questionnaire (Hendratmi et al., 2019). After the data collection, the obtained data were analyzed using descriptive analysis.

\section{Results and Discussion}

The results of the online survey are analyzed descriptively. There were five constructs for discussion in this paper, namely: (1) Perceived usefulness, (2) Perceived easy to use, (3) Use of social media, (4) Islamic crowdfunding model, and (5) Donors' intention to use of the Islamic donation-based crowdfunding platform model. From Table I, we can see a summary of the results from the online survey.

Table I. The Summary of the Results from Online Survey

\begin{tabular}{|c|c|c|c|c|c|c|c|}
\hline No. & Construct & Indicator & SA & $\mathbf{A}$ & $\mathbf{N}$ & $\mathbf{D}$ & SD \\
\hline \multirow{6}{*}{1} & \multirow{6}{*}{ Perceived usefulness (PU) } & Donate more quickly & 49 & 78 & 50 & 9 & 7 \\
\hline & & Donation performance & 49 & 74 & 52 & 12 & 6 \\
\hline & & Increase donation productivity & 41 & 75 & 61 & 11 & 5 \\
\hline & & Effectiveness & 49 & 81 & 43 & 13 & 7 \\
\hline & & Make donation easier & 50 & 79 & 44 & 15 & 5 \\
\hline & & Useful & 55 & 81 & 38 & 14 & 5 \\
\hline \multirow{6}{*}{2} & \multirow{6}{*}{ Perceived ease to use (PEU) } & Easy to use & 48 & 82 & 47 & 10 & 6 \\
\hline & & Controllable & 40 & 73 & 57 & 18 & 5 \\
\hline & & Clear and understandable & 39 & 83 & 54 & 11 & 6 \\
\hline & & Flexibility & 37 & 83 & 52 & 15 & 6 \\
\hline & & Easy to become skillful & 30 & 77 & 63 & 19 & 4 \\
\hline & & Easy of learn & 37 & 80 & 61 & 9 & 6 \\
\hline \multirow{4}{*}{3} & \multirow{4}{*}{ Use of social media (USM) } & Get more information & 75 & 72 & 25 & 12 & 9 \\
\hline & & Help to know about programs & 71 & 81 & 22 & 11 & 8 \\
\hline & & Increase interest in donation & 58 & 81 & 34 & 11 & 9 \\
\hline & & Easy to collect donation funds & 78 & 73 & 21 & 11 & 10 \\
\hline \multirow{3}{*}{4} & \multirow{3}{*}{$\begin{array}{l}\text { Islamic crowdfunding } \\
\text { information (ICI) }\end{array}$} & Help to donate safely & 53 & 78 & 35 & 17 & 10 \\
\hline & & Increase awearness to donate & 58 & 82 & 32 & 11 & 10 \\
\hline & & Increase a trust to donate & 55 & 76 & 41 & 12 & 9 \\
\hline \multirow{2}{*}{5} & \multirow{2}{*}{ Donors' Intention to Use (DIU) } & Intention to donate & 41 & 73 & 61 & 10 & 8 \\
\hline & & Planned to utilization & 40 & 81 & 54 & 14 & 4 \\
\hline
\end{tabular}

Note: SA = Strongly Agree, A = Agree, $\mathrm{N}=$ Neutral, D = Disagree, SD = Strongly Disagree

Source: Survey (2020)

\section{Perceived Usefulness}

The first construct is perceived usefulness. According to Darmansyah et al. (2020) defines that perceived usefulness is the degree to which a person believes using a particular system will improve his/her work performance and will effect on the intention to adopt financial technology (fintech) 
products and services (Huei et al., 2018). Meanwhile, Ratri (2016) perceived usefulness has a strongly significant impact and important variable to influence attitude, behavior, and intention to accept the new concept in financial technology products and services. There were six indicator items to measure perceived usefulness in this study i.e. donate more quickly, donation performance, increase donation productivity, effectiveness, make donation easier, and useful (all indicators are duplicated from Davis (1989) and Ratri (2016)).

In Figure 2, the results of the online survey show that most of the respondents have strongly agreed and agreed with using the Islamic donation-based crowdfunding model that would be useful for supporting donation activities. Thus, the model would help them to donate more quickly (78/193 agreed), increase their donation performance (74/193 agreed) and productivity (75/193 agreed), effectiveness (81/193 agreed), and make donations easier (79/193 agreed), as well as useful (81/193 agreed) in supporting the financing program for MSMEs in times of Covid-19. pandemic in Indonesia.

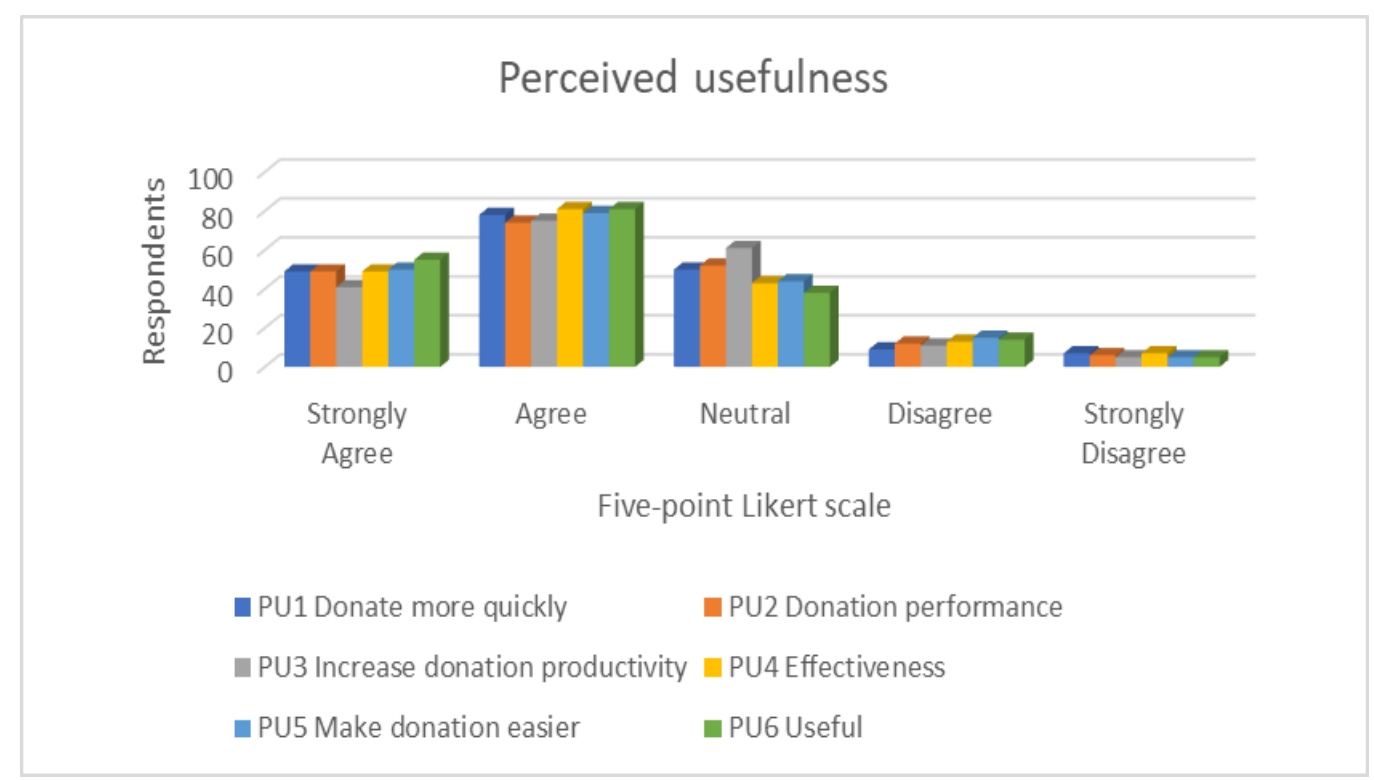

Source: Author's Computation (2020)

Figure 2. The Result of the Online Survey for Perceived Usefulness

\section{Perceived Ease to Use}

The second construct is perceived ease to use. Same as perceived usefulness, perceived ease to use has a positive effect on intentions to adopt financial technology (fintech) products and services (Huei et al., 2018). Where Davis (1989) stated perceived ease to use is a belief individually that using a certain technology would be easier. He said also perceived ease to use influences the intention, usefulness, attitude, and actualization of using technology. Hence, there were six indicator items to measure perceived usefulness in this study i.e. easy to use, controllable, clear and understandable, flexibility, easy to become skillful, and also easy to learn of the Islam donationbased crowdfunding platform model (all indicators are duplicated from Davis (1989) and Ratri (2016)).

Empirically, Figure 3 shows the results of the online survey which almost all respondents have agreed with using financial technology especially the Islamic donation-based crowdfunding platform model would be easier in donation activities. The respondents believe that the platform model would be easy to use (82/193 agreed), controllable (73/193 agreed), clear and understandable (83/193 agreed), flexibility (83/193 agreed), easy to become skillful (77/193 agreed), and also easy to learn (80/193 agreed). Particularly, the model provides the financing program for MSMEs in times of Covid-19. pandemic. 


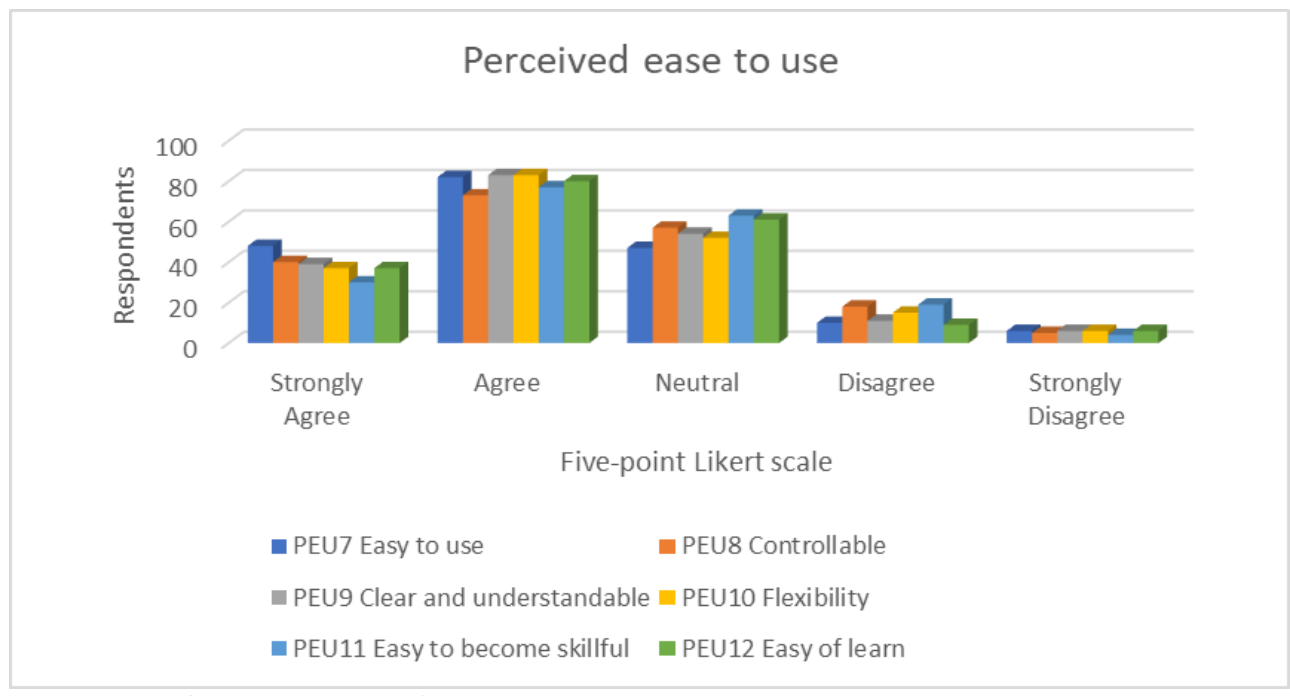

Source: Author's Computation (2020)

Figure 3. The Result of the Online Survey for Perceived Ease to Use

\section{Use of Social Media}

The third construct is the use of social media. Social media has a direct impact on the behavioral intention of using the fintech concept. For the Islamic donation-based crowdfunding platform model to work effectively, the model must be engaged in using social media, i.e. Facebook, Instagram, Twitter, and so on. This is because of the key driver of crowdfunding success in any country. The results of the online survey, in Figure 4, almost all respondents (strongly) agreed with using social media would help them to get more information (where 75/193 strongly agreed and 72/193 agreed) and also to know about the donation programs in the platform (where 81/193 agreed and 71 strongly agreed). Furthermore, they also strongly agreed that using social media would help them to increase their interest in donation programs (where 81/193 agreed), and using social media would be easy to collect donation funds (73/193 agreed). Similarly, Choy and Schlagwein (2016) mentioned that crowdfunding takes advantage of social networking to raise funds globally. Therefore, social media would help to promote and campaign about the financing programs for MSMEs in times of Covid-19. pandemic.

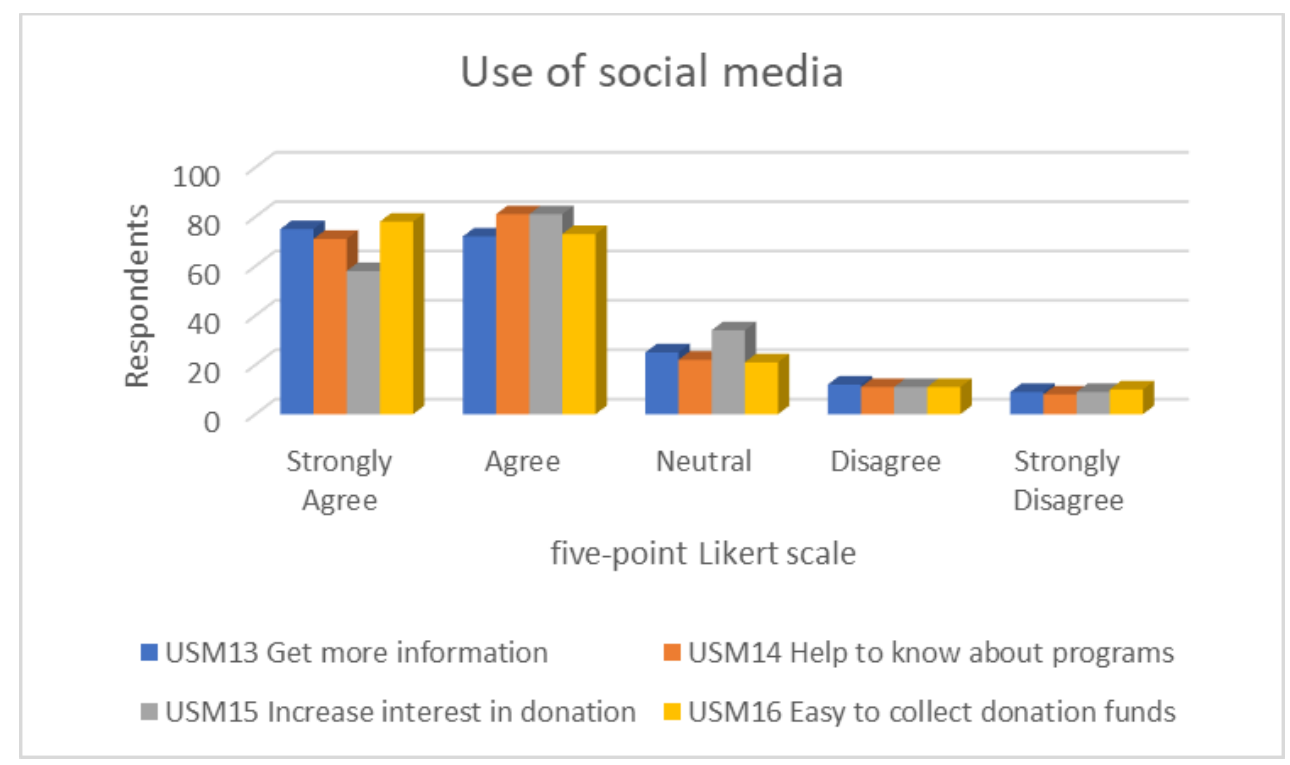

Source: Author's Computation (2020)

Figure 4. The Result of the Online Survey for Use of Social Media 


\section{Islamic Crowdfunding Information}

The fourth construct is Islamic crowdfunding information. The information on Islamic crowdfunding would influence individual participation in social programs. Nonetheless, low information also could affect the adoption of the fintech concept (Pikkarainen et al., 2004), because the lack of information is the major obstacles that hinder its adoption. Therefore, information about Islamic crowdfunding is very important, and the campaign positively influences the donors to use the Islamic donation-based crowdfunding platform. Based on the results from an online survey, most respondents stated strongly agreement (agreed) which Islamic donation-based information would help them to donate safely (78/193 agreed), and increase their awareness (82/193 agreed), as well as increase their trust to donate (76/193 agreed) in the platform especially to support the financing program for MSMEs in times of Covid-19. pandemic in Indonesia (see Figure 5).

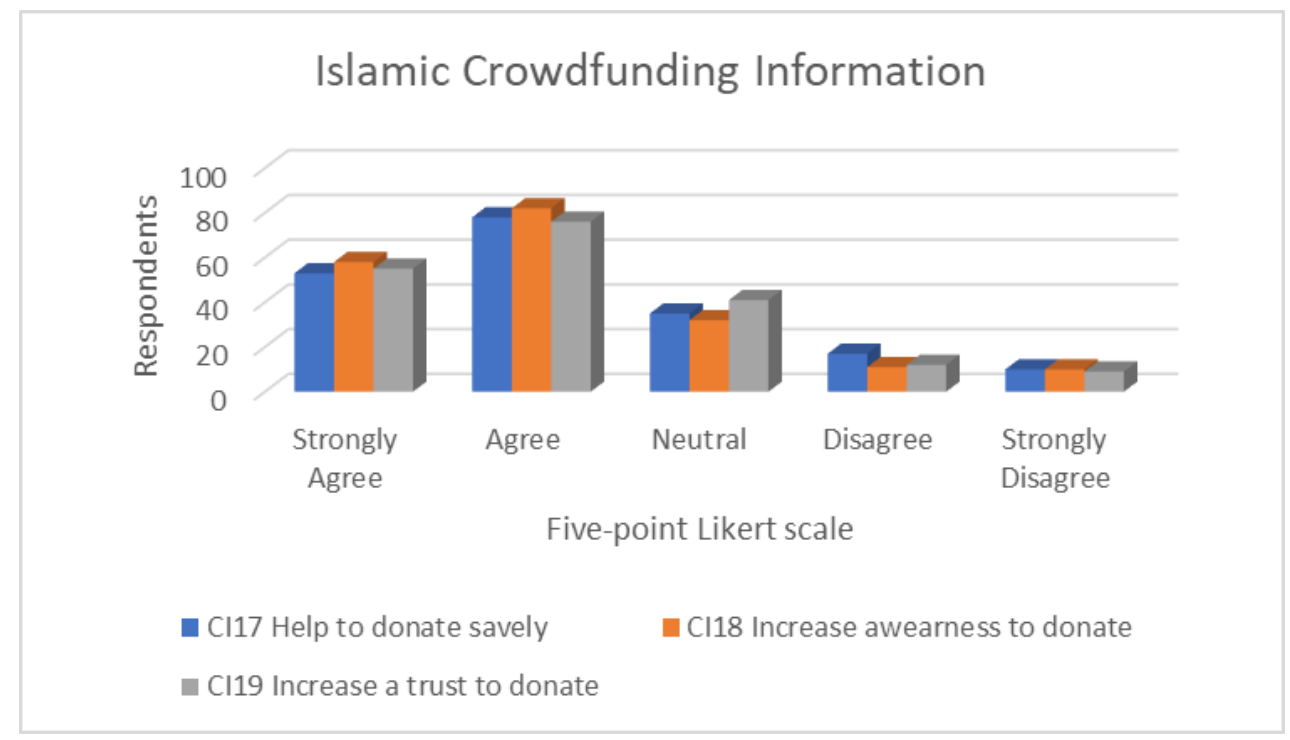

Source: Author's Computation (2020)

Figure 5. The Result of the Online Survey for Islamic Crowdfunding Information

\section{Donors' Intention to Use}

The last construct is donors' intention to use the Islamic donation-based crowdfunding platform model and also planned to utilization in the future. Ratri (2016) stated that planned utilization in the future is one of the indicators to the intention of individuals to the actual use of the technology. The results of the online survey show that most of the respondents agreed and strongly agreed, where 81/193 agreed and 40/193 strongly agreed. They would use the Islamic donation-based crowdfunding platform model as a priority platform in the future. Therefore, respondents have the intention to donate (where 71/193 agreed and 41/193 strongly agreed) in the program of financing for MSMEs by using the Islamic donation-based crowdfunding platform model (see Figure 6).

In summary, the majority of all respondents accepted to use the Islamic donation-based crowdfunding platform model based on an online survey and they have the intention to donate using this platform. However, there were still existing respondents who answered with disagreeing/strongly disagree and even the neutral. They still have favored doing donation as normal ways (without using technological concept) to participate in the financing program for MSMEs in time of the COVID-19 pandemic. 


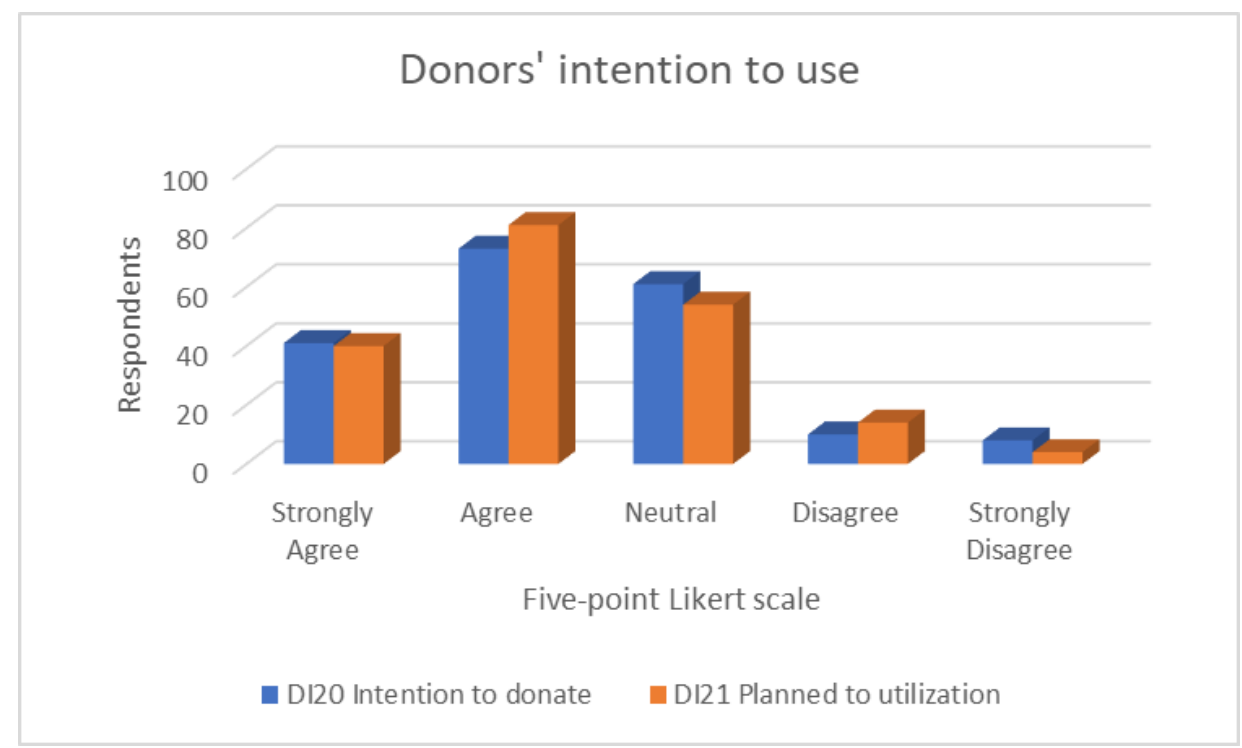

Source: Author's Computation (2020)

Figure 6. The Result of the Online Survey for Donors'Intention to Use

\section{Conclusion}

As a global pandemic today, the negative impact of Covid-19. has been affecting many sectors especially MSMEs in Indonesia. There need for solutions that will help to alleviate and resolve the problems from the effects of the Covid-19. pandemic in Indonesia. This paper presents the potential of Islamic donation funds (zakat, waqf, sadaqah, and other charities) and the concept of the Islamic crowdfunding. Hence, the author discussed proposing the concept of the Islamic donation-based crowdfunding platform model. The platform that can be potentially adopted to provide financial services for the MSMEs especially during the crisis like Covid-19. in Indonesia. Furthermore, the platform model will open the opportunity for more optimum and impactful utilization of zakat or sadaqah, and the like and will help the government and policymakers to plan appropriate intervention strategies to minimize the damages of the Covid-19. pandemic on MSMEs in Indonesia.

Furthermore, an empirical study has been conducted to this study that used an online survey questionnaire to test the acceptance practicality of the idea about the concept of the Islamic donation-based crowdfunding model. Overall, the majority of all respondents accepted to use the Islamic donation-based crowdfunding platform model. Where the respondents have strongly agreed to donate through the platform model because the platform model would be a usefulness and easier. Social media and Information about Islamic crowdfunding also would help to promote and campaign all the financing programs as well as influence individual participation. Additionally, the respondents have an intention to donate in the program of financing MSMEs by using the Islamic donation-based crowdfunding platform model in times of Covid-19. pandemic in Indonesia. Additionally, this study will add to the existing literature in the areas of the Islamic donation-based crowdfunding platform model as an alternative strategy to minimize the negative impact of the Covid-19. pandemic on MSMEs in Indonesia.

\section{Recommendation}

In this study, the recommendations are made by the author, which are: (1) For a Crowdfunding Operator (CFO), they must be a task force institution that is pointed directly by the government and focused on the utilize of Islamic donation funds for MSMEs in times of Covid-19. pandemic. CFO also could under supervised by BAZNAS (Badan Amil Zakat Nasional or the National Board of Zakat) as the highest government zakat institution or other possible institutions in Indonesia. 
Moreover, $\mathrm{CFO}$ should collaborate with Islamic FinTech providers to create the system more secure of its online platform. This is because of the risk exposure for the online platform should be minimized by enhancing the security of virtual transactions. Besides that, to make the system more effective and transparent, the model could use the Artificial Intelligence (AI) and Natural Language Process (NLP) such as recommended by Haider and Khan (2020). Furthermore, CFO also should promote to enhance awareness on the use of the platform model in Indonesia. (2) Finally, for government, policymakers, zakat institutions, waqf institutions, and other relevant authorities, they should synergize togetherly to realize the concept of the Islamic donation-based crowdfunding platform model into the real-world.

\section{Acknowledgment}

Sulaeman is a master's student in Science of Islamic Economics Program, Faculty of Economics and Business, University of Airlangga, Surabaya, Indonesia. His study is fully funded by Lembaga Pengelola Dana Pendidikan (LPDP) Scholarships.

\section{References}

Abdullah, R., \& Ismail, A. G. (2017). Taking stock of the waqf-based Islamic microfinance model. International Journal of Social Economics, 44(8), 1018-1031. https:/ / doi.org/10.1108/IJSE-062015-0176

Achsien, I. H., \& Purnamasari, D. L. (2016). Islamic crowd-funding as the next financial innovation in Islamic finance: Potential and anticipated regulation in Indonesia. Islamic Crowd-Funding as The Next Financial Innovation in Islamic Finance: Potential and Anticipated Regulation in Indonesia, (5), 1-11. https://doi.org/10.13135/2421-2172/1771

Ascarya. (2020). The role of Islamic social finance in times of Covid-19 outbreak. Pusat Ekonomi \& Bisnis Syariah, Fakultas Ekonomi dan Bisnis, Universitas Islam, Jakarta. Retrieved from https://pebs-febui.org/en/download/materi-monthly-seminar-the-role-of-islamic-socialfinance-in-times-of-Covid-19-outbreak-4-april-2020/

Aulia, M., Yustiardhi, A. F., \& Permatasari, R. O. (2020). An overview of Indonesian regulatory framework on Islamic financial technology (fintech). Journal Ekonomi \& Kenangan Islam, 6(1), 64-75. https://doi.org/10.20885/JEKI.vol6.iss1.art7

Aziz, M. R., Johari, F., \& Yusof, M. A. (2013). Cash waqf models for financing in education. 5th Islamic Economic System Conference: Proceedings of a Conference, 835-842. Kuala Lumpur, Malaysia: Universiti Sains Islam Malaysia.

Belleflamme, P., Lambert, T., \& Schwienbacher, A. (2014). Crowdfunding: Tapping the right crowd. Journal of Business Venturing, 29(5), 585-609. https://doi.org/10.1016/j.jbusvent.2013.07.003

Chamani, A., Anshory, A., Hudaefi, F. A., Junari, U. L., \& Zaenal, M. H. (2020). The role of zakat institution in preventing COVID-19. Policy Brief March 2020, (March).

Che Hassan, S. N. A., \& Rahman, A. A. (2018). The potential of cash waqf in the socio-economic development of society in Kelantan. In New Developments in Islamic Economics (pp. 67-82). https://doi.org/10.1108/978-1-78756-283-720181005

Choy, K., \& Schlagwein, D. (2016). Crowdsourcing for a better world: On the relation between IT affordance and donor motivations on charitable crowdfundin. Informational Technology \& People, 29(1), 221-247. https://doi.org/10.1108/ITP-09-2014-0215

Cizakca, M. (1995). Cash waqfs of bursa, 1555-1823. Journal of the Economic and Social History of the Orient, 38(3), 313-354. https://doi.org/10.1163/1568520952600407 
Darmansyah, D., Fianto, B. A., Hendratmi, A., \& Aziz, P. F. (2020). Factors determining behavioral intentions to use Islamic financial technology. Journal of Islamic Marketing, abead-of- $p$ (aheadof-print). https://doi.org/10.1108/JIMA-12-2019-0252

Davis, F. D. (1989). Perceived usefulness, perceived ease of use, and user acceptance of information technology. MIS Quarterly, 13(3), 319. https://doi.org/10.2307/249008

Dresner, S. (2014). Crowdfunding: A Guide to Raising Capital on the Internet. New York, NY.: John Wiley $\&$ Sons.

Firdaus, M., Beik, I. S., \& Irawan, T. (2012). Economic estimation and determinations of zakat potential in $\begin{array}{llll}\text { Indonesia } & \text { No. 1433-07). } & \text { Retrieved }\end{array}$ http://mfirdaus.staff.ipb.ac.id/files/2016/02/WP-1433-07.pdf

Haneef, M. A., Huq, A., Mohammed, M. O., \& Amin, F. B. (2013). Integration of waqf and Islamic microfinance for poverty reduction: A survey in Kuala Selangor, Malaysia. Journal of Islamic Finance, 2(2), 1-16.

Harahap, B. A., Idham, P. B., Kusuma, A. C. M., \& Rakhman, R. N. (2017). Perkembangan financial technology terkait central bank digital currency (CBDC) terhadap transmisi kebijakan moneter dan makroekonomi. Bank Indonesia, 2, 1-80. Retrieved from http://publicationbi.org/repec/idn/wpaper/WP022017.pdf

Hendratmi, A., Ryandono, M. N. H., \& Sukmaningrum, P. S. (2019). Developing Islamic crowdfunding website platform for startup companies in Indonesia. Journal of Islamic Marketing, abead-of-p(ahead-of-print). https://doi.org/10.1108/JIMA-02-2019-0022

Hidajat, T. (2019). Unethical practices peer-to-peer lending in Indonesia. Journal of Financial Crime, 27(1), 274-282. https://doi.org/10.1108/JFC-02-2019-0028

Huei, C. T., Suet Cheng, L., Chee Seong, L., Aye Khin, A., \& Ling Leh Bin, R. (2018). Preliminary study on consumer attitude towards FinTech products and services in Malaysia. International Journal of Engineering \& Technology, 7(2.29), 166. https://doi.org/10.14419/ijet.v7i2.29.13310

Iman, A. H. M., \& Mohammad, M. T. S. H. (2017). Waqf as a framework for entrepreneurship. Humanomics, 33(4), 419-440. https://doi.org/10.1108/H-01-2017-0015

Indrawan, I. W., \& Herman, S. (2017). Integrated zakeat and waqf model for refugees (IZWMR), Proposal to Improve Livelibood of Global Refugees. 1-10. Retrieved from https://www.academia.edu/37451559/Integrated_Zakat_and_Waqf_Model_for_Refuge es_IZWMR_Proposal_to_Improve_Livelihood_of_Global_Refugees

Kachkar, O. A. (2017). Towards the establishment of cash waqf microfinance fund for refugees. ISRA International Journal of Islamic Finance, 9(1), 81-86. https://doi.org/10.1108/IJIF-072017-007

Kashif, M., Jamal, K. F., \& Rehman, M. A. (2018). The dynamics of zakat donation experience among Muslims: a phenomenological inquiry. Journal of Islamic Accounting and Business Research, 9(1), 45-58. https://doi.org/10.1108/JIABR-01-2016-0006

Marzban, S., Asutay, M., \& Boseli, A. (2014). Shariah-compliant crowd funding: An efficient framework for entrepreneurship development in Islamic CSR and sustainable development in Islamic banking in Malaysia view project mathematic modeling for risk-sharing contracts view project. Harvard Islamic Finance Forum, 02(April), 272. https://doi.org/10.13140/RG.2.1.2696.1760

Mauluddin, M. I., \& Rahman, A. A. (2018). Cash waqf from the perspective of Majelis Ulama Indonesia (MUI) and the scholars of Aceh: An analysis. New Developments in Islamic Economics (pp. 49-66). https://doi.org/10.1108/978-1-78756-283-720181004 
Mohammad, M. T. S. H. (2011). Towards an Islamic social (Waqf) Bank. International Journal of Trade, Economics and Finance, 2(5), 381-386. https://doi.org/10.7763/IJTEF.2011.V2.135

Mohammad, M. T. S. H. (2015). Theoretical and trustees' perspectives on the establishment of an Islamic social (Waqf) bank. Humanomics, 31(1), 37-73. https://doi.org/10.1108/H-052013-0032

Mollick, E. (2014). The dynamics of crowdfunding: An exploratory study. Journal of Business Venturing, 29(1), 1-16. https://doi.org/10.1016/j.jbusvent.2013.06.005

Mukhlisin, M., Ascarya, Pasumah, B. T., Antonio, M. S., Yasid, M., Mulyana, R., \& Tamanni, L. (2020). Tujub paket kebijkan ekonomi dan keuangan syariab mengatasi dampak krisis COVID-19. Bogor. Retrieved from http://mysharing.co/tujuh-paket-ekonomi-dan-keuangan-syariahmengatasi-dampak-krisis-Covid-19/

Pikkarainen, T., Pikkarainen, K., Larjaluoto, H., \& Pahnila, S. (2004). Consumer acceptance of online banking: an extension of the technology acceptance model. Internet Research, 14(3), 224-235.

Puskas Baznas. (2020). Dampak COVID-19 terhadap pekerja rentan Indonesia. Policy Brief March 2020, PB2020-III, 1-21. Retrieved from https://puskasbaznas.com/publications/policybrief/1201-dampak-Covid-19-terhadappekerja-rentan-indonesia

Raimi, L., Patel, A., \& Adelopo, I. (2014). Corporate social responsibility, Waqf system and Zakat system as faith-based model for poverty reduction. World Journal of Entrepreneurship, Management and Sustainable Development, 10(3), 228-242. https://doi.org/10.1108/WJEMSD-09-2013-0052

Ramos, J. (2015). Crowdfunding and the role of managers in ensuring the sustainability of crowdfunding platforms third main title line third line. https://doi.org/10.13140/RG.2.1.3925.6480

Ratri, S. M. (2016). Analisis faktor-faktor yang memengarubi penggunaan e-learning moodle oleh guru SMK Negeri 2 Yogyakarta dengan pendekatan Technology Acceptance Model (TAM). Yogyakarta. Retrieved from https://eprints.uny.ac.id/33545/

Riza, A., \& Hafizi, M. (2020). Customers attitude toward Islamic mobile banking in Indonesia: Implementation of TAM. Asian Journal of Islamic Management, 1(2), 75-84. doi:https://doi.org/10.20885/ajim.vol1.iss2.art1

Samad, A., \& Glenn, L. M. (2010). Development of zakah and zakah coverage in monotheistic faiths. International Journal of Social Economics, 37(4), 302-315. https://doi.org/10.1108/03068291011025264

Sangwan, V., Harshita, H., Prakash, P., \& Singh, S. (2019). Financial technology: a review of extant literature. Studies in Economics and Finance, 37(1), 71-88. https://doi.org/10.1108/SEF-072019-0270

Sitanggang, L. M. S. (2019). Punya potensi hingga Rp 77 triliun, BWI kaji penjaminan investasi wakaf uang. Retrieved April 4, 2020, from Kontan.co.id website: https://keuangan.kontan.co.id/news/punya-potensi-hingga-rp-77-triliun-bwi-kajipenjaminan-investasi-wakaf-uang?page $=$ all

Suhaili, N. A., \& Palil, M. R. (2016). Crowdfunding: A collaborative waqf based internet platform. International Journal of Business, Economics and Law, 11(5), 41-46. Retrieved from https://www.researchgate.net/publication/318200553

Sulistiyo, A., Wardayati, S., Hidayatullah, A., \& Riesky, S. (2020). Effect of Islamic corporate governance on customer trust: empirical study on Islamic bank. Asian Journal of Islamic 
Management, 2(1), 12-24. https://doi.org/10.20885/ajim.vol2.iss1.art2

Thaker, M. A. B. M. T. (2018). Factors influencing the adoption of the crowdfunding-waqf model (CWM) in the waqf land development. Journal of Islamic Marketing, 9(3), 578-597. https://doi.org/10.1108/JIMA-05-2016-0043

Thaker, M. A. B. M. T., Mohammed, M. O., Duasa, J., \& Abdullah, M. A. (2016). Developing cash waqf model as an alternative source of financing for micro enterprises in Malaysia. Journal of Islamic Accounting and Business Research, 7(4), 254-267. https://doi.org/10.1108/JIABR09-2014-0029

Tohirin, A. (2010). The cash waqf for empowering the small businesses. Paper Presented at 7th International Conference - The Tawhidi Epistemology: Zakat and Waqf Economy, Bangi, Selangor.

Victoria, A. O. (2020). Sri Mulyani Sebut Covid-19 Lebih Kompleks dari Krisis 1998 dan 2008. Retrieved April 30, 2020, from https://katadata.co.id/berita/2020/04/07/sri-mulyanisebut-Covid-19-lebih-kompleks-dari-krisis-1998-dan-2008 
Appendix 1. Distribution of respondents by gender, age and marital status

\begin{tabular}{|c|c|c|}
\hline Respondents' characteristic & Frequency & $\%$ \\
\hline \multicolumn{3}{|l|}{ Gender } \\
\hline Male & 104 & 53.9 \\
\hline Female & 89 & 46.1 \\
\hline \multicolumn{3}{|l|}{ Age group } \\
\hline Under 20 & 4 & 2.1 \\
\hline $21-30$ & 122 & 63.2 \\
\hline $31-40$ & 47 & 24.4 \\
\hline $41-50$ & 7 & 3.6 \\
\hline Above 50 & 13 & 6.7 \\
\hline \multicolumn{3}{|l|}{ Marital status } \\
\hline Single & 93 & 48.2 \\
\hline Married & 99 & 51.3 \\
\hline Others & 1 & 0.5 \\
\hline \multicolumn{3}{|l|}{ Educational level } \\
\hline Elementary school & 0 & 0 \\
\hline Junior high school & 0 & 0 \\
\hline Senior high school & 15 & 7.8 \\
\hline Diploma & 2 & 1 \\
\hline Bachelor & 131 & 67.9 \\
\hline Master & 40 & 20.7 \\
\hline $\mathrm{PhD}$ & 5 & 2.6 \\
\hline \multicolumn{3}{|l|}{ Occupational } \\
\hline Public & 28 & 14.5 \\
\hline Private & 54 & 28 \\
\hline Self-employed & 21 & 10.9 \\
\hline Teacher & 9 & 4.7 \\
\hline Student & 53 & 27.5 \\
\hline Housewife & 17 & 8.8 \\
\hline Others & 11 & 5.7 \\
\hline \multicolumn{3}{|l|}{ Level income } \\
\hline Less than 3 million & 70 & 36.3 \\
\hline 3-5 million & 71 & 36.8 \\
\hline 6-9 million & 32 & 16.6 \\
\hline $10-15$ million & 14 & 7.3 \\
\hline 16-20 million & 2 & 1 \\
\hline more than 20 million & 4 & 2.1 \\
\hline \multicolumn{3}{|l|}{ Level expenditure } \\
\hline less than 2 million & 62 & 32.1 \\
\hline $2-4$ million & 86 & 44.6 \\
\hline 5-7 million & 31 & 16.1 \\
\hline 8-10 million & 9 & 4.7 \\
\hline more than 10 million & 5 & 2.6 \\
\hline
\end{tabular}

